\title{
PRAKTIK AKAD MURABAHAH PRODUK PEMBIAYAAN HUNIAN SYARIAH DI BANK MUAMALAT CABANG PURWOKERTO
}

\author{
Anita Khaerunnisa, Mintaraga Eman Surya \\ Universitas Muhammadiyah Purwokerto, Email : anita.khoerunisa23@gmail.com \\ Universitas Muhammadiyah Purwokerto, Email : mintaragaesurya@gmail.com
}

\begin{abstract}
ABSTRAK
Pembiayaan Hunian Syariah pada Bank Muamalat cabang Purwokerto adalah produk pembiayaan membantu usaha nasabah dapat membeli, membangun ataupun merenovasi properti maupun pengalihan take-over pembiayaan properti dari bank lain. Tujuan penelitian untuk mengetahui dan menganalisa praktik akad murabahah pada produk pembiayaan hunian syariah. Penelitian ini merupakan penelitian lapangan dengan menggunakan pendekatan kualitatif, yang bertujuan untuk mengetahui aplikasi akad Murabahah Produk Pembiayaan Hunian Syariah dan mengetahui adakah perbedaan antara teori dan praktik pada akad Murabahah dilihat dari kesesuaian dengan Fatwa Dewan Syariah Nasional MUI No.04/DSN-MUI/IV/2000. Sumber data adalah wawancara, dokumentasi, observasi dan data sekunder yang diperoleh literatur yang berkaitan dengan masalah yang diteliti. Hasil penelitian ini menunjukkan bahwa praktik akad Murabahah Produk Pembiayaan Hunian Syariah. Akad yang digunakan adalah murabahah (jual beli) dengan margin, terutama untuk rumah yang telah dibangun yaitu pemesan barang (rumah) dengan kriteria dan persyaratan tertentu yang disepakati, serta pembayaran dengan nilai tertentu yang telah disepakati pula.
\end{abstract}

Kata-kata kunci : Pembiayaan, Akad, Murabahah

\begin{abstract}
Sharia Residential Financing at Bank Muamalat Purwokerto branch is a financing product that helps customers businesses to buy, build or renovate properties and transfer take-over property financing from other banks. The purpose of the study was to find out and analyze the practice of murabahah contracts on Islamic residential financing products. This research is a field research using a qualitative approach, which aims to determine the application of the Murabahah Sharia Financing Product contract and find out whether there is a difference between the theory and practice of the Murabahah contract seen from its compatibility with the MUI National Sharia Council Fatwa No.04 / DSN-MUI / IV / 2000. Data sources are interviews, documentation, observations and secondary data obtained by the literature relating to the problem under study. The results of this study indicate that the practice of the Murabahah Sharia Financing Product contract. The contract used is
\end{abstract}


murabahah (sale and purchase) with margin, especially for houses that have been built, namely ordering goods (houses) with certain agreed criteria and requirements, as well as payments with certain agreed values.

Keywords: Financing, Contract, Murabahah

\section{PENDAHULUAN}

Setiap makhluk hidup membutuhkan tempat tinggal atau hunian, tidak kecuali manusia. Hunian tersebut merupakan kebutuhan yang mendasar dan memiliki fungsi yang sangat penting. Akan tetapi masih banyak masyarakat yang belum memiliki hunian khususnya bagi masyarakat yang berpenghasilan rendah. Bagi masyarakat yang berpenghasilan rendah sangat sulit memiliki hunian secara tunai. Oleh sebab itu, bank syariah menyediakan suatu produk untuk memudahkan masyarakat dalam memenuhi kebutuhan akan hunian yaitu dengan adanya produk Pembiayaan Hunian Syariah.

Pembiayaan hunian syariah haruslah terhindar dari praktik maisir (perjudian), gharar (ketidakjelasan), dan riba (tambahan). Bank membeli barang yang diperlukan nasabah atas nama bank sendiri, dan pembelian ini harus sah dan bebas riba. Bank kemudian menjual barang tersebut kepada nasabah (pemesan) dengan harga jual senilai harga beli plus keuntungannya. Dalam kaitan ini bank harus memberitahu secara jujur harga pokok barang kepada nasabah berikut biaya yang diperlukan. nasabah kemudian membayar harga barang yang telah disepakati tersebut pada jangka waktu tertentu yang telah disepakati. Untuk mencegah terjadinya penyalahgunaan atau kerusakan akad tersebut, pihak bank dapat mengadakan perjanjian khusus dengan nasabah.

Harga jual hunian ditetapkan diawal ketika nasabah menandatangani perjanjian pembiayaan hunian syariah, dengan angsuran tetap hingga jatuh tempo pembiayaan. Dengan adanya kepastian jumlah angsuran selesai, nasabah tidak akan dipusingkan dengan masalah naik atau turunnya angsuran ketika suku bunga bergejolak. Nasabah juga diuntungkan ketika ingin melunasi angsuran sebelum masa kontrak berakhir, karena bank syariah tidak akan mengenakan pinalti. Bank syariah tidak memberlakukan sistem pinalti karena harga hunian syariah sudah ditetapkan sejak awal. 
Pembiayaan Hunian Syariah merupakan salah satu produk pada bank Muamalat yang menggunakan sistem murabahah pada operasionalnya. Pembiayaan hunian syariah ini merupakan pembiayaan yang disediakan untuk pembiayaan kepada nasabah untuk kepemilikan rumah. Dalam pelaksanaan sistem murabahah di perbankan syariah khususnya dalam pembiayaan kepemilikan rumah, perlu mendapat peninjauan lebih lanjut. Diketahui bahwa sistem Murabahah dapat kita lihat dari aspek akad, uang muka dan iuran perbulan. Bagaimana kemudian penerapan ketiga aspek ini dalam perbankan syariah ketika diterapkan. Akad dalam suatu bentuk kerjasama mutlak ada karena akad ini menjadi legalitas dari kedua belah pihak. Uang muka diberikan di awal akad sebagai tanda jadi akan suatu pembelian serta iuran perbulan ini merupakan kewajiban pembeli atas barang yang dibelinya ketika barang tersebut tidak dibeli secara tunai.(Harnia, 2012:13)

Kehadiran pembiayaan hunian syariah yang diberikan oleh bank syariah dapat menghindari resiko naik turunnya bunga. Pembiayaan hunian syariah tidak mengenal sistem bunga namun memakai harga penjualan rumah yang disepakati, ditambah dengan keuntungan bagi bank yang berkisar $15-20 \%$ per tahun. Secara hitungan matematis, pembiayaan hunian syariah sebenarnya tidak berbeda jauh dalam jumlah cicilan bulanan di konvensional, walaupun umumnya sedikit lebih mahal. Namun keuntungan menggunakan pembiayaan hunian syariah adalah jika margin-nya naik bergejolak, karena sudah sepakat mengenai harga jual dan keuntungan pertahun diawal perjanjian, nasabah selamanya akan mencicil sejumlah yang disepakati dari awal hingga berakhirnya masa jangka berkala. Status bank syariah dalam pembiayaan hunian syariah adalah sebagai pedagang, karena bank membeli langsung dari pihak developer secara penuh. Setelah hunian tersebut dibeli oleh bank syariah, secara otomatis hunian tersebut menjadi milik bamk secara penuh. Kemudian nasabah membelinya dari bank secara berangsur.

Ada beberapa bentuk pembiayaan untuk keperluan peningkatan usaha atau biasa dikenal dengan prinsip jual beli, pembiayaan produktif Islam yang diberikan oleh bank Islam, yaitu pembiayaan dengan prinsip jual beli, pembiayaan atas dasar prinsip bagi hasil sesuai dengan kesepakatan, pembiayaan atas prinsip bagi hasil yang porsinya disesuaikan 
dengan proporsisi penyertaan dan pembiayaan yang berdasarkan prinsip sewa jual. Pembiayaan berdasarkan prinsip jual beli bagi nasabah yang menginginkan tambahan aset yang diperoleh melalui jual beli yang pada akhirnya bertujuan untuk menjadi kepemilikan aset tersebut pada nasabah. Pembiayaan yang diperuntukan untuk pemenuhan kebutuhan nasabah yang bersifat konsumtif baik berupa hunian atau kendaraan bermotor terdiri dari dua bentuk, yaitu pembiayaan berdasarkan prinsip jual beli dan berdasarkan sewa beli.

Bagi masyarakat yang memiliki kemampuan dalam keuangan, membeli sebuah rumah secara tunai bukanlah kendala. Namun, bagi masyarakat yang memiliki keterbatasan keuangan, membeli rumah secara tunai menjadi kendala. Sehingga banyak masyarakat yang memilih membeli rumah melalui pembiayaan secara berkala. Hal ini dikarenakan pembayaran secara berkala dianggap lebih ringan dibandingkan pembayaran secara tunai. Seperti kalangan usaha kecil dan menengah mendapatkan peluang baru untuk memanfaatkan pembiayaanpembiayaan yang ditawarkan oleh Bank Muamalat. Jadi untuk semakin mendorong minat kalangan usaha kecil dan menengah untuk bekerja sama dengan lembaga keuangan syariah. Kebutuhan masyarakat terhadap pembiayaan hunian membuat bank mengeluarkan produk pembiayaan, yaitu seperti Pembiayaan Hunian Syariah.

\section{METODE PENELITIAN}

Jenis penelitian ini adalah metode kualitatif. Data diperoleh berbagai sumber, dengan menggunakan teknik pengumpulan data yang bermacam-macam (triangulasi), dan dilakukan secara terus menerus sampai datanya jenuh. Dengan pengamatan yang terus menerus tersebut mengakibatkan variasi data tinggi sekali. Data yang diperoleh pada umumnya adalah data kualitatif, sehingga teknik analisis data yang digunakan belum ada polanya yang jelas. Oleh karena itu sering mengalami kesulitan dalam melakukan analisis (Sugiyono, 2014: 87). Metode penelitian kualitatif adalah metode penelitian yang digunakan untuk meneliti pada kondisi obyek alamiah, (sebagai lawannya adalah eksperimen) dimana peneliti adalah sebagai instrumen kunci, teknik pengumpulan data dilakukan secara analisis data bersifat induktif dan 
hasil penelitian kualitatif lebih menekankan makna dari pada generalisasi.

Obyek penelitian ini adalah Bank Muamalat Cabang Purwokerto yang secara khusus memberikan layanan perbankan dengan menggunakan prinsip-prinsip syariah. Teknik pengumpulan data dalam penelitian ini adalah observasi, wawancara, dan dokumentasi. Untuk menganalisis data yang telah diperoleh dari hasil penelitian, peneliti menggunakan analisa deskriptif kualitatif, yaitu analisis yang mewujudkan bukan dalam bentuk angka melainkan dalam bentuk lapangan dan uraian deskriptif. Adapun untuk cara yang digunakan untuk menganalisa data dalam hal ini dengan menggunakan metode analisis deduktif yakni analisis data dari umum ke khusus sesuai dengan data yang diperoleh peneliti. Kemudian temuan tersebut akan dipelajari dan dianalisis sehingga bisa lebih dibuat suatu kesimpulan. Serta dianalisis dengan data yang ada sehingga dapat diketahui kesesuaian penerapan Fatwa DSN-MUI tentang Murabahah pada Bank Muamalat Cabang Purwokerto.

\section{HASIL DAN PEMBAHASAN}

Murabahah adalah adalah akad jual beli barang dengan menyatakan harga perolehan dan keuntungan (margin) yang disepakti oleh penjual dan pembeli. Akad ini merupakan salah satu bentuk natural certainty contracts, karena dalam murabahah ditentukan berapa required rate of profit-nya (keuntungan yang ingin diperoleh). Karena dalam definisinya disebut adanya "keuntungan yang disepakati", karakteristik murabahah adalah si penjual harus memberi tahu pembeli tentang harga pembelian barang dan menyatakan jumlah keuntungan yang ditambahkan pada biaya tersebut.(Karim, 2011: 113). Murabahah sendiri adalah sebuah transaksi jual beli di mata si penjual menyebutkan harga kulakan dari komoditina kepada si pembeli, untuk kemudian si pembeli membelinya dengan memberikan selisih harga lebih kepada si penjual sebagai keuntungan, dan keuntungan tersebut ditentukan sesuai dengan kesepakatan kedua belah pihak. Dalam transaksi murabahah bank-bank Islam tidak turut menanggung untung dan rugi, melainkan lebih banyak menerima peran intermediasi finansial klasik. (Mahmud, 2014: 94). Menurut Mazhab Hanafiah, pengertian jual beli secara definitif, yiatu tukar menukar harta benda atau sesuatu yang diinginkan dengan sesuatu yang sepadan melalui 
cara tertentu yang bermanfaat. Sedangkan menurut Malikiyah, Syafi'iyah dan Hanabilah, bahwa jual beli yaitu tukar menukar harta dengan harta pula dalam bentuk pemindahan milik dan kepemilikan. (Mardani, 2011:168). Menurut Sayyid Sabiq yang dimaksud jual beli adalah pertukaran harta atas dasar saling rela. Atau memindahkan milik dengan ganti yang dapat dibenarkan (yaitu berupa alat tukar yang sah). (Wajdi, 2012:139).

PT Bank Muamalat Tbk (Bank Muamalat Indonesia) memulai perjalanan bisnisnya sebagai Bank Syariah pertama di Indonesia pada 1 November 1991 atau 24 Rabi'us Tsani 1412 H. Pendirian Bank Muamalat Indonesia digagas oleh Majelis Ulama Indonesia (MUI), Ikatan Cendekiawan Muslim Indonesia (ICMI) dan pengusaha muslim yang kemudian mendapat dukungan dari Pemerintah Republik Indonesia. Sejak resmi beroperasi pada 1 Mei 1992 atau 27 Syawal 1412 H, Bank Muamalat Indonesia terus berinovasi dan mengeluarkan produk-produk keuangan syariah seperti Asuransi Syariah (Asuransi Takaful), Dana Pensiun Lembaga Keuangan Muamalat (DPLK Muamalat) dan multifinance syariah (Al-Ijarah Indonesia Finance) yang seluruhnya menjadi terobosan di Indonesia. Selain itu produk Bank yaitu Shar-e yang diluncurkan pada tahun 2004 juga merupakan tabungan instan pertama di Indonesia. Produk Shar-e Gold Debit Visa yang diluncurkan pada tahun 2011 tersebut mendapatkan penghargaan dari Museum Rekor Indonesia (MURI) sebagai Kartu Debit Syariah dengan teknologi chip pertama di Indonesia serta layanan e-channel seperti internet banking, mobile banking, ATM, dan cash management. Seluruh produk-produk terseut menjadi pionir produk syariah di Indonesia dan menjadi tonggak sejarah penting di industri perbankan syariah. Adapun produk pembiayaan di Bank Muamalat Purwokerto sebagai berikut :

1. KPR iB Muamalat. Peruntukkan badan usaha dalam negeri (non-asing) yang memiliki legilitas di Indonesia. KPR Muamalat iB adalah produk pembiayaan yang akan membantu untuk memiliki rumah tinggal, rumah susun, apartemen dan condotel termasuk renovasi dan pembangunan serta pengalihan (take-over) KPR dari bank lain dengan dua pilihan akad yaitu akad murabahah (jual-beli) dan musyarakah mutanaqishah (kerjasama sewa). Keuntungan dari KPR iB Muamalat 
yaitu:

a. Sesuai dengan pinsip syariah

b. Angsuran tetap hingga akhir pembiayaan sesuia perjanjian dengan akad murabahah

c. Margin 9,5\% untuk 2 tahun pertama, selanjutnya mengikuti ketentuan selama program masih berlaku

d. Uang ringan mulai dari $10 \%$

e. Plafond pembiayaan lebih besar

f. Jangka waktu pembiayaan maksimal 15 tahun

g. Berlaku untuk nasabah baru dan nasabah eksisting Bank Muamalat

h. Dapat diajukan oleh pasangan suami istri dengan sumber penghasilan untuk angsuran diakui secara bersama (joint income).

2. Pembiayaan iB Muamalat Pensiun. Pembiayaan iB Muamalat Pensiun merupakan produk pembiayaan yang membantu untuk memenuhi kebutuhan di hari tua dengan sederet keuntungan dan memenuhi prinsip syariah yang menenangkan. Produk ini memfasilitasi pensiunan untuk kepemilikan dan renovasi rumah tinggal, pembelian kendaraan, biaya pendidikan anak, biaya pernikahan anak dan umroh. Termasuk take over pembiayaan pensiun dari bank lain. Dua pilihan yaitu akad murabahah (jual beli) dan ijarah multijasa. Keuntungan dari Pembiayaan iB Muamalat Pensiun yaitu:

a. Sesuai dengan prinsip syariah

b. Angsuran tetap hingga akhir pembiayaan perjanjian

c. Uang muka ringan

d. Plafond pembiayaan maksimal Rp 100.000 .000 tanpa agunan

e. Jangka waktu pembiayaan sampai dengan 10 tahun

f. Berlaku untuk nasabah baru dan nasabah eksisting Bank Muamalat

g. Pembiayaan dicover dengan asuransi jiwa

h. Angsuran pembiayaan dipotong langsung dari manfaat pensiun bulanan.

3. Pembiayaan iB Muamalat Multiguna. Pembiayaan iB Muamalat Multiguna merupakan produk pembiayaan yang membantu untuk memenuhi kebutuhan barang jasa konsumtif seperti bahan bangunan untuk merenovasi rumah, kepemilikan sepeda motor, biaya pendidikan, biaya pernikahan dan perlengkapan rumah. Dalam pembiayaan iB 
multiguna ada dua pilihan akad yaitu akad murabahah (jual beli) dan ijarah multijasa (sewa jasa). Keuntungan pembiayaan iB multiguna yaitu:

a. Menenangkan karena sesuai dengan prinsip syariah

b. Angsuran tetap hingga akhir pembiayaan sesuai dengan perjanjian

c. Uang muka ringan

d. Plafond pembiayaan lebih besar

e. Jangka waktu pembiayaan maksimal 5 tahun

f. Pembiayaan sampai dengan Rp 50.000.000 tidak perlu agunan

g. Berlaku untuk nasabah baru dan nasabah eksisting Bank Muamalat

h. Mudah, dapatkan dana pembiayaan dengan persyaratan pengajuan yang mudah dan proses persetujuan yang singkat

Pembiayaan hunian syariah adalah produk pembiayaan yang akan membantu usaha anda untuk membeli, membangun ataupun merenovasi properti maupun pengalihan take-over pembiayaan properti dari bank lain untuk kebutuhan bisnis. Pemenuhan aspek syariah pada pembiayaan hunian syariah (pembiayaan al-murabahah sebagaimana gambar berikut :

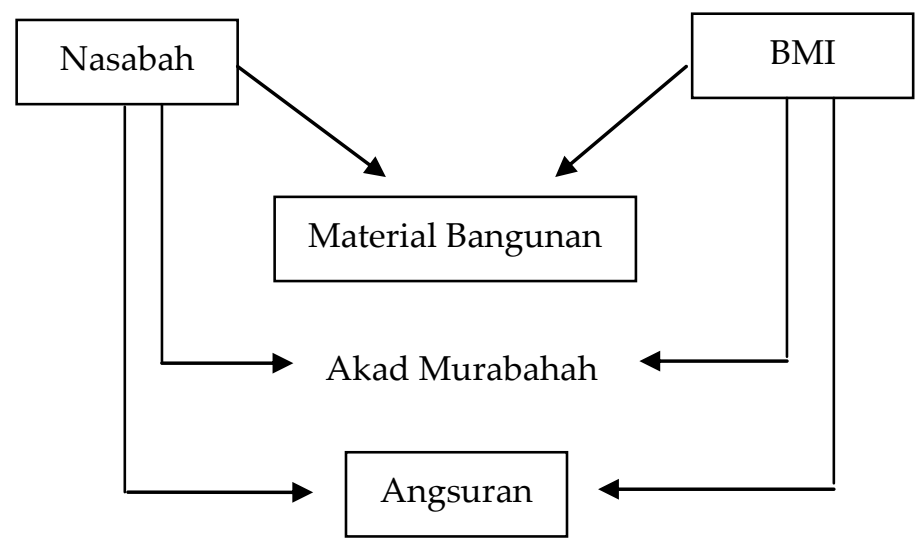

Aspek syariah atas pembiayaan ini terpenuhi dengan syarat sebagai berikut:

1. Nasabah memerlukan pembelian material bangunan dari Bank Muamalat Indonesia (BMI)

2. Nasabah dan Bank Muamalat Indonesia bekerjasama pembelian material bangunan akad al-Murabahah

3. Nasabah membayar angsuran kepada Bank Muamalat Indonesia (BMI). 
Skema Akad Wakalah bila Murabahah para nasabah mengajukan pembiayaan kepada lembaga keuangan syariah. Tahap awal mengajukan pembiayaan adalah permohonan pembiayaan. Secara formal, permohonan pembiayaan dilakukan secara tertulis, seperti dengan form aplikasi pembiayaan. Hal yang sama juga dilakukan oleh Bank Muamalat dalam proses pembiayaan hunian syariah sebelumnya mengisi formulir aplikasi pengajuan khusus Pembiayaan Hunian Syariah. Kemudian setelah diisi formulirnya tersebut diserahkan ke Relationship Manager untuk diproses.

Analisis pembiayaan dapat dilakukan dengan berbagai metode sesuai dengan kebijakan bank yaitu, melalui karakter dengan melihat karakter nasabah melalui wawancara, dan karakter nasabah dapat dijawab semua dengan mudah dan yakin. Karena bank harus selektif dalam hal profil tentang nasabah. Kapasitas, analisa diarahkan pada kemamopuan dari sumber penghasialn calon nasabah membiayai seluruh pengeluaran bulanannya. Dengan melihat kapasitas atau kemampuan nasabah mengangsur dalam hal cash ratio. cash ratio adalah rasio perbandingan antara total pendapatan per bulan setelah dikurangi dengan biaya bulanan dan kewajiban-kewajiban perbulan lainnya dengan angsuran perbulan. Jaminan, analisa ini diarahkan terhadap jaminan yang diberikan. Jaminan adalah asset nasabah yang dijanjikan kepada bank jika nasabah tidak dapat mengangsur pembiayaan. Jaminan yang dimaksud harus bisa mencover risiko pembiayaan nasabah. Modal tidak perlu karena pembiayaan rumah termasuk pembiayaan yang bersifat konsumtif, jadi bukan untuk usaha. Kondisi ekonomi sangat mempengaruhi keadaan nasabah, misalnya kondisi ekonomi memburuk yang menyebabkan terjadinya PHK yang akan menyebabkan kemampuan nasabah membayar angsuran jadi bermasalah. Purpose yaitu untuk mengetahui tujuan nasabah dalam mengambil pembiayaan. Dalam hal ini nasabah bertujuan ingin memiliki rumah. Untuk menjada objektifitas sebuah analisa, sebuah analisa, biasanya dilakukan analisa oleh seberapa orang ataupun unit kerja.

1. Jika disetujui lembaga keuangan syariah akan mengeluarkan SP3 (surat pernyataan penghentian penyelidikan). Offering letter (surat penawaran) beserta dokumen lain jika tidak disetujui akan dibuatkan rejection letter: form pesanan barang kepada bank (promise to purchuse) dan kuasa pembelian (akad wakalah); 
2. Berbekal surat wakalah ini maka nasabah boleh melakukan pembelian atas nama bank dan boleh juga menalangi uang pembelian kepada bank;

3. Nasabah melakukan pembelian barang yang dimaksud (boleh) secara non tunai, supplier memberikan invoice sebagai wujud akad menjual. Dengan demikian maka barang secara prinsip telah menjadi milik bank lewat wakalah kepada nasabah;

4. Bank dan nasabah melakukan akad pembiayaan murabahah;

5. Bank melakukan pembayaran uang kepada supplier;

6. Supplier menyerahkan barang kepada nasabah sedang kuitansi kepada bank;

7. Bank melakukan pengecekan, sebelum proses pembelian dilakukan sebelumnya pemerikasaan terlebih dahulu terhadap semua kelengkapan yang harus dipenuhi sesuai disposisi komite pada proposal pembiayaan;

8. Nasabah mengangsur kepada bank;

9. Praktik Akad Murabahah Produk Pembiayaan Hunian Syariah di Bank Muamalat Cabang Purwokerto

Praktek akad murabahah pembiayaan hunian syariah di Bank Muamalat Indonesia, jika nasabah ketika ingin membutuhkan barang (rumah atau bahan material bangunan) tetapi nasabah tidak memiliki dana untuk membeli obyek tersebut. Maka nasabah mengajukan pembiayaan ke bank, membantu pembelian rumah dengan menggunakan produk KPR, misalnya nasabah ingin membeli rumah tapi dengan melalui bank Muamalat dengan menggunakan akad murabahah yaitu jual beli rumah dengan mencari margin sesuai kesepakatan bersama antara nasabah dan bank muamalat. Murabahah itu akad jual beli yang unsurnya ada harga beli, ada margin (laba/keuntungan), ada harga jual, ada uang muka.

Hambatan akad murabahah pembiayaan hunian syariah yaitu, syarat-syarat pengajuan dari nasabah misalnya ingin membeli rumah tetapi belum mempunyai IMB (ijin mendirikan bangunan), dari persyaratan jaminan, setiap nasabah ingin menganjukan pembiayaan dilihat dari segi by checking yaitu historical nasabah diseluruh bank jadi bisa ketahuan hutangnya nasabah atau baik buruknya diseluruh bank-bank. Misalny histori nasabahnya buruk atau terlalu banyak pembiayaan di bank-bank 
lain maka tidak boleh mengajukan pembiayaan.

Kesesuaian akad murabahah produk pembiayaan hunian syariah di Bank Muamalat Indonesia cabang Purwokerto sudah sesuai dengan Fatwa DSN-MUI No.04/DSN/IV/2000. Kesesuaian akad murabahah produk pembiayaan hunian syariah di Bank Muamalat Cabang Purwokerto sudah sesuai dengan Fatwa DSN-MUI No.04/DSN/IV/2000 yaitu ketentuannya sebagai berikut :

1. Terbebas dari riba

Dalam produk pembiayaan hunian syariah di bank Muamalat cabang Purwokerto tidak ditemukan adanya unsur riba, karena sudah sesuai dengan prosedur adanya persyaratan tertentu apa yang dibutuhkan yang harus diajukan ke bank dan dalam membebani administrasi atau pembayaran dengan nilai tertentu dari nasabah sudah ditetapkan diawal yang telah disepakati dan tidak ada penambahan biaya. Uang muka atau dalam istilah perbankan syariahnya urbun, untuk produk pembiayaan hunian syariah ini sendiri pihak perbankan menetapkan urbun 30\% dari total pembayaran. Namun perlu dipahami bahwa, pihak perbankan menerapkan urbun atau uang muka sebagai salah satu bentuk kehati-hatian dalam memberikan pembiayaan kepada nasabah. Uang muka ini juga jadi bukti keseriusan antara kedua belah pihak untuk melakukan pembiayaan dan tanda jadi dari pembelian. Perlu dipahami bahwa perbankan syariah juga merupakan lembaga keuangan yang ingin mendapatkan keuntungan namun dengan jalan yang sesuai dengan syariat. Maka penerapan uang muka ini perlu dipahami oleh nasabah sebagai salah satu bentuk kehati-hatain perbankan dalam meminimalisir resiko yang mungkin akan timbul dan dalam ajaran Islam hal ini dibenarkan oleh ulama untuk muka pada pembiayaan.

2. Barang halal yang diperjual belikan

Bank Muamalat Cabang Purwokerto menjual barang kepada nasabah adalah barang yang benar jelas halalnya dan sesuai dengan syariat. Kemudian secara spesifikasinya pengambilan barang harus jelas, antara lain dengan syarat jual beli adalah barang benar-benar dikuasai oleh penjual, terus dari segi wujudnya jelas lalu baru bisa 
diakadkan yang diikatkan dalam suatu perjanjian yang telah disepakati oleh kedua belah pihak, antara pihak nasabah dan pihak bank.

3. Kejelasan akad

Dalam pembiayaan hunian syariah akad yang digunakan di bank muamalat adalah akad murabahah dan musyarakah mutanaqishah. Penerapan akad murabahah dalam perbankan syariah seperti yang diterapkan dalam produk pembiayaan hunian syariah yaitu dengan nasabah yang hendak memiliki rumah namun tidak mampu membeli secara finansial dapat mengajukan bantuan permohonan pembiayaan kepada bank. Setelah nasabah mengajukan permohonan pembiayaan kepada pihak bank dan telah jelas tipe rumah yang akan dibeli maka pihak perbankan kemudian mencarikan rumah yang dimaksud tersebut. Dengan terlebih dulu pihak bank membeli rumah tersebut dan setelah menjadi milik bank, maka rumah tersebut dijual kembali kepada nasabah yang mengajukan pembiayaan dengan tambahan margin keuntungan, dan pembayarannya dilakukan secara mengangsur. penjelasannya misalnya nasabah mau beli rumah, harga rumah yang mau dibeli $\mathrm{Rp} 250.000 .000$. terus nasabah punya uang $\mathrm{Rp}$ 50.000.000, jadi kurangnya untuk beli rumah makanya nasabah mengajukan pembiayaan ke bank. Sedang harga rumah Rp 250.000.000, kemudian plafon pengajuan KPR ke bank Rp 200.000.000 (harga beli).

Jadi, harga beli (plafon KPR) : Rp 200.000.000

Nasabah

: Rp 50.000.000

Harga jual bank ke nasabah KPR dengan jangka waktu 10 tahun

: Rp 300.000.000

Margin bank

: harga jual-harga beli Rp 300.000.000-Rp

$$
200.000 .000=\text { Rp 100.000.000. }
$$

4. Bank menyampaikan semua hal-hal yang berkaitan dengan pembelian

Bank Muamalat Cabang Purwokerto akan menyampaikan informasi kepada pihak nasabah apa yang sudah menjadi kualifikasinya dalam hal margin keuntungan yang akan diambil oleh pihak bank sehingga tersampaikan kepada nasabah harga jual yang disepakati. Dalam proses penyaluran pembiayaan hunian syariah ini benar harus diutamakan keterbukaan antara kedua belah pihak 
nasabah dan pihak bank. Nasabah dengan jelas mengutarakan rumah seperti apa yang beliau inginkan kemudian pihak bank membeli rumah yang dimaksud kemudian dijual kembali kepada nasabah dengan margin keuntungan yang telah disampaikan sebelumnya, lalu nasabah kemudian membayarnya angsuran kepada bank dengan total angsuran tetap berpengaruh pada jangka waktu tertentu. Lama atau tidaknya waktu pelunasan angsuran nasabah kepada bank tetap dan tidaknya berubah hingga masa pelunasan jatuh tempo.

Berdasarkan wawancara dengan nasabah, awal mulanya ingin membeli rumah tetapi kendala dalam hal biaya, jadinya memilih untuk menganjukan pembiayaan hunian syariah di Bank Muamalat Purwokerto. Oleh sebab itu karena ketertarikannya dalam sistemnya yang digunakan yaitu menggunakan sistem margin keuntungan bukan menggunakan sistem bunga yang sangat jelas riba dan nasabah sudah mengetahui bahwa pembiayaan ini sesuai dengan syariah. Kemudian dari pihak bank sendiri telah menjelaskan mengenai hal-hal apa yang diperjual belikan sesuai dengan persyaratan tertentu, jadi dari pihak bank tersendiri tidak ada unsur untuk penipuan. (Wawancara dengan nasabah Bapak Andika Kholifah, 23 Juli 2018)

5. Penyelesaian hutang dalam Murabahah

Penyelesaian hutang pada pembiayaan hunian syariah yaitu misalnya nasabah sudah akad di bank tetapi dipertengahan jalan nasabah tidak bisa mengangsur makanya pihak bank menawarkan restruktur yaitu meringankan cicilan selama jangka waktu tertentu sampai keadaan ekonomi nasabah pulih. Kemudian selanjutnya jual jaminan sukarela yaitu jika nasabah harus menjual jaminan untuk membayar di bank muamalat dan lelang adalah proses membeli dan menjual barang atau jasa dengan cara menawarkan kepada penawar, menawarkan tawaran harga lebih tinggi, dan kemudian penjual barang penawar harga tertinggi. Namun harga dari hasil penjualan tersebut tidak sepenuhnya milik bank yang menyalurkan pembiayaan. Akan tetapi dari hasil penjualan tersebut bank hanya mengambil berdasarkan sisa harga pokok yang pasti dibayarkan nasabah kepada bank. Apabila rumah tersebut dijual dengan harga lebih tinggi melebihi 
pokok, maka sisa dari penjualan tersebut tetap menjadi hak milik nasabah. Hal ini dikarenakan rumah tersebut telah dibeli nasabah dan telah mengangsurnya kepada bank.

\section{SIMPULAN}

Bank Muamalat Indonesia menawarkan produk-produk dalam akad Murabahah yaitu seperti produk KPR (kredit pemilikan rumah) jual beli rumah, antara lain rumah baru dan rumah bekas, pembelian barang halal dan barang konsumtif yaitu pembelian bahan material renovasi rumah dan bangun rumah, pembelian konsumtif beragunan konsumtif properti yaitu misalnya mobil, perabot rumah tangga dan sebagainya. Kesesuaian fatwa DSN-MUI pada produk Murabahah di Bank Muamalat Indonesia Cabang Purwokerto dalam prakteknya telah sesuai. Karena dalam prosedur dari pengajuannya telah sesuai dengan syarat yang berlaku.

Bank Muamalat telah menerapkan bebas biaya, bebas biaya pelunasan sebagian, fleksibel sesuai dengan kemampuan nasabah. Misalnya nasabah ingin membeli rumah tapi dengan melalui bank Muamalat dengan menggunakan akad murabahah yaitu jual beli rumah dengan mencari margin sesuai kesepakatan bersama margin antara nasabah dan bank muamalat. Murabahah itu akad jual beli yang unsurnya ada harga beli, ada margin (laba/keuntungan), ada harga jual, ada uang muka. Pelunasan dipercepat sebagian: tidak dikenakan biaya penalti atau administrasi, dapat mengurangi angsuran atau memperpendek jangka waktu pembiayaan, dapat dilakukan kapan saja. Pelunasan dipercepat seluruhnya: tidak dikenakan biaya penalti atau administrasi dan dapat diberi diskon dari harga jual murabahah.

\section{DAFTAR REFERENSI}

Karim, Adiwarman. (2011). Bank Islam Analisis Fiqih dan Keuangan. Jakarta: Rajawali Pers

Mardani, Dr. (2011). Hukum Ekonomi Syariah di Indonesia. Bandung: PT Refika Aditama

Mujahidin, A. (2016). Hukum Perbankan Syariah. Jakarta: PT Rajagrafindo Persada

Muhammad. (2014). Manajemen Dana Bank Syariah. Jakarta: PT Rajagrafindo 
Persada

Mustofa, Ahmad, Priyadi, unggul, Dr, M.si, Mahmudi. (2014). Reorientasi Ekonomi Syariah. Yogyakarta: UII Press

Perwataatmadja, Karnaen. (1992). Apa Dan Bagaimana Bank Islam. Yogyakarta: PT Dana Bhakti Prima Yasa

Sarwono, Jonathan. (2006). "Metode Penelitian”. Kuantitatif Kualitatif.

http://www.academia.edu.documents/3356965/metodepenelitian-131012025

140-phpapp01.docx? Diakses pada tanggal 5 April 2018

Satori, Djam’an, Dkk. (2011). Metodologi Penelitian Kualitatif. Bandung: Alfabeta

Soeratno. (1993). Metodologi Penelitian. Yogyakarta: Akademi Manajemen Perusahaan YKPN

Sugiyono, Prof. Dr. (2014). Memahami Penelitian Kualitatif. Bandung: Alfabeta

Syafi'i Antonio, Muhammad. (2001). Bank Syariah Dari Teori ke Praktik. Jakarta: Gema Insani

Wadji, Farid. (2012). Hukum Ekonomi Islam. Jakarta: Sinar Grafika

Harnia. (2012). Analisis Penerapan Sistem Murabahah Pada Pembiayaan Hunian Syariah Muamalat (Studi pada Bank Muamalat Makassar). http://repository.uin-alauddin.ac.id diakses pada tanggal 7 April 2018

Fauziah. (2011). Analisis Aplikasi Produk Murabahah Pada Pembiayaan Hunian Syariah PT Bank Muamalat Indonesia. http://repository.uinjkt.ac.id diakses pada tanggal 7 April 2018

Rika Koesnaini, Dewi. (2015). Analisis Akad Murabahah Dalam Produk Pembiayaan Hunian Syariah (Perspektif Hukum Perpajakan dan Perlindungan Konsumen). http://repository.uinjkt.ac.id diakses pada tanggal 7 April 2018

Nuzulul Mabruroh, Sayyidah. (2015). Praktek Pembiayaan Hunian Syariah Antara Akad Murabahah dan Akad Musyarakah Mutanaqishah di Bank Muamalat Cabang Malang. http://repository.uinmalang.ac.id diakses pada tanggal 7 April 2018

http://dsn-mui.or.id diakses pada tanggal 27 Maret 2018 www.bankmuamalat.co.id diakses pada tanggal 5 April 2018 